\title{
The United States Position towards the Battle of Al-Karameh and its Repercussions, March 21, 1968
}

\author{
By Yousef Omar*
}

\begin{abstract}
This paper explores the United States' position towards the battle for Al-Karameh and its repercussions on the 21 March 1968. It argues that even though American policy has always been completely biased in favor of Israel since Israel's founding on 15 May 1948, its position on the battle of Al-Karameh was at the time considered supportive of Israel, balanced with Jordan, and hostile to Palestinian organizations. The United States position in the research relies mainly on the documents of the US State Department (Foreign Relations of the United States FRUS) and on some of the minutes of the Israeli parliament (Knesset) sessions (Knesset Foreign Affairs and Defense Committee meetings). This research dealt with an introduction to the crystallization of the Palestinian resistance after the defeat of the Arabs in the Six-Day War of 1967 as well as the policy of the United States towards the region after this war, its position on the escalation of Palestinian resistance from inside Jordan, and the dialectic of Jordan's control of its territories and borders. It also dealt with the incident of the bombing of the Israeli bus on 18 March 1968, and the escalation of tension, which eventually led to Israel attacking Jordan in the battle for Al-Karameh on 21 March 1968, the initial American reaction to it, and the subsequent issuance of Security Council Resolution 248 and its implications. It further dealt with the official American position after the battle ended, its support for the efforts of the Jarring Peace Mission in the region, and its policy of balancing its positions between Israel and Jordan. In conclusion, reference was made to the most important results of the research.
\end{abstract}

\section{Introduction}

Israel declared war on Egypt, Jordan, and Syria on 5 June 1967, which Israel called the "Six-Day War" and the Arabs called it Naksa "Setback". It ended with the victory of Israel, the defeat of the Arabs for the third successive time, and Israel's occupation of the Sinai, Gaza Strip, the West Bank (includes East Jerusalem) and the Golan. ${ }^{1}$

The defeat of the Arabs in this war and the failure of Gamal Abdel Nasser's national policy led to a major change, as Palestinian refugees no longer waited for the Arab armies to liberate Palestine from Israel as they had before and decided that they would carry out their own armed struggle to achieve it. $^{2}$

Palestinian organizations initially tried to work among the local population in the occupied territories. Still, they did not achieve much success

\footnotetext{
*Associate Professor, Al- Aqsa University, Palestine.

1. Jim Zanotti, "Palestinians: Background and U. S. Relations", Congressional research service, 8 January 2010, 45; Rachael Hanel, Days of Change: The Israeli-Palestinian Conflict (Minnesota: The Creative C. Education, 2007), 26.

2. "1968: Karameh and the Palestinian revolt", Telegraph, 1 May 2002. https://www. telegraph.co.uk/news/1400177/1968-Karameh-and-the-Palestinian-revolt.html
} 
in that. One of the reasons for this was that Israel prevented contact between the leadership of the Palestinian people and the residents of the occupied Palestinian territories and Jerusalem ${ }^{3}$, so Palestinian organizations, such as Fatah movement, led by Yasser Arafat (1 January 1965 - 11 November 2004), the Popular Front for the Liberation of Palestine and other smaller organizations, launched attacks on Israeli targets starting from Jordan due to the presence of a large number of Palestinian refugees there, which provided them with a large popular incubator, in addition to the presence of the longest borders that helped them in carrying out military operations against Israel. ${ }^{4}$

The Al-Karameh ${ }^{5}$ town and the adjacent small Palestinian refugee camp, just a few kilometers away from the new ceasefire lines separating Jordanian and Israeli forces, was a major base for Palestinian organizations and Palestinian fighters locally referred to as "Fedayeen" (Palestinian fighters who are ready to fight Israel and sacrifice themselves for the Palestinian cause). ${ }^{6}$

The fact that Palestinian organizations launched military operations against Israel from Jordan had caused Israel to carry out revenge operations, which had come to be known as "Reprisal operations"7. Nevertheless, at the beginning of 1968, these organizations, headed by the largest and most powerful Fatah movement, continued to attack Israel from their bases in Jordan, which resulted in Israeli human and material losses ${ }^{8}$. King Hussein (11 August 1952 - 7 February 1999) did not succeed in neutralizing the Palestinian military presence in the town of Al-Karameh and along the Jordanian border, and by March 1968, there were hundreds of civilians living in the town of AlKarameh, along with about 900 from Fedayeen - most of them from Fatah movement - who had opened their headquarters in Al-Karameh. ${ }^{9}$

3. Knesset Foreign Affairs and Defense Committee meetings, June 1967 - June 1968: the complete transcripts. Part 2, 20 February 1968: Transcript No. 107.

4. James Ciment, World Terrorism: An Encyclopedia of Political Violence from Ancient Times to the Post-9/11 Era (London: Routledge, 2011), 295-6.

5. Al-Karameh: A town in central Jordan, near the Allenby Bridge which spans the Jordan River. The river defines the border between Jordan and the Israeli-occupied West Bank.

6. "Battle of Al-Karama, A Triggering Moment for the Palestinian Resistance", Palestinian journeys. https://www.paljourneys.org/en/timeline/highlight/165/battle-al-ka rama

7. Moshe Gat, Britain and the Conflict in the Middle East, 1964-1967: The Coming of the Six-Day War (Westport: Praeger, 2003), 124.

8. Spencer C Tucker and Priscilla Roberts, Encyclopedia of the Arab-Israeli Conflict, The: A Political, Social, and Military History, Vol. I, (Santa Barbara: ABC-CLIO, 2008), 569-570.

9. Benny Morris, Righteous Victims: A History of the Zionist-Arab Conflict, 1881-1999 (New York: Vintage Books, 2001), 368. 


\section{United States' Policy towards the Region after the 1967 War}

The 1967 war had sparked a lot of speculation about the influence and policy of the United States in the region, so Nicholas Katzenbach, US Undersecretary of State (3 October 1966 - 20 January 1969), summarized the National Security Council meeting on the Near East. On 21 February 1968, the United States' position stated that there was no indication of the fact that the influence of the United States in the region had deteriorated due to the recent war, but that Soviet influence, in turn, was increasing. It added that the United States has lost some influence due to its relationship with Israel and the last Arab-Israeli war under the natural growth of Arab nationalism. ${ }^{\mathbf{1 0}}$

Eugene V Rostow, Under Secretary of State for Political Affairs (14 October 1966 - 20 January 1969), made the matter more specialized when he expressed his concern about the situation in Jordan and considered King Hussein to be in a real dilemma because the Palestinian organizations had resisted Israel while he wanted to move toward a peaceful settlement with Israel but did not dare do so on his own. Rostow stated that the Israeli ambassador to Washington Yitzak Rabin (1968-1973) informed the US State Department that he hoped King Hussein would finally realize that if he wanted to survive he would have to control "terrorism"11. He added that it would increase King Hussein's chances of survival because if the Palestinian organizations had the upper hand, King Hussein would lose control of his country in the end. It was also made clear to the Jordanian people that they were ultimately victims of the Palestinian organizations and that if he used sufficient force against Palestinian organizations he could remain king. ${ }^{12}$

In light of these challenges, King Hussein sent a letter dated 2 March 1968 AD, to American President Lyndon Johnson (22 November 1963 - 20 January 1969), in which he emphasized his "warm close" relationship with the United States, which brings the two countries together for a long period. He added that he was pleased to receive President Johnson's confirmation that he had previously sent stating that the policy and interest of the United States was the continuation of this relationship with Jordan and that all the tensions and problems created by the six-day war did not change the basic US policy toward Jordan. He further stated that the arms deal presented by the chief of

10. Memorandum for the Record, Washington, Subject: National Security Council Meeting on the Near East, 21 February 1968.

All American documents in this study are from: Foreign Relations of the United States (FRUS), 1964-1968, Volume XX, Arab-Israeli Dispute, 1967-1968.

11. There is an old debate about defining acts of violence, especially when there are two contradictory points of view. Violence against Israel is considered by the Palestinian people and its supporters to be "resistance", and Israel and its supporters to be "terrorism".

12. Document (Doc). 120292. 1, Telegram From the Department of State to the Embassy in Israel, Washington, 24 February 1968, 1908Z. 
staff of the Jordanian Armed Forces, Major General Amer Khammash (9 October 1967 - 27 October 1968), to the United States was aimed at meeting Jordan's legitimate requirements of acquiring weapons to confront the huge problems facing Jordan. King Hussein declared that he had great hope that the deal would be agreed upon in the end to enable him to overcome the problems facing him. ${ }^{13}$

It is understood from this message that this deal may have been to confront Palestinian organizations that are launching military operations against Israel from Jordan in light of Jordan's permanent declaration of its desire to reach a peace agreement with Israel.

On 12 March 1968, the US Department of State announced that it was pleased with King Hussein's desire to end negotiations to conclude the arms deal between the two countries as soon as possible and requested the American Ambassador to Amman Harrison M. Symmes (18 October 1968 - 7 May 1970) to tell the Jordanian government that the United States would increase the number of M48A1 tanks from 88 to 100 tanks, 40-mm selfpropelled anti-aircraft guns from 4 to 24 cannons, and $50-\mathrm{mm}$ anti-aircraft guns from 9 to 100 cannons, in addition to many weapons parts, and that the United States cannot go about supplying weapons to Jordan any longer. ${ }^{14}$

It is clear from the quantity and quality of weapons, even with the criterion of armament at the time, that these weapons were primarily defensive rather than offensive weapons, and they were certainly not able to break the strategic balance with Israel but could make a difference in Jordan's ability to deal with Palestinian armed organizations. These organizations had power and influence inside Jordan and could threaten the rule of King Hussein or perhaps change the monarchy later, which is something that King Hussein may have feared personally.

\section{The United States and the Dialectic of Jordan's Control of its Borders}

The American ambassador to Amman, Harrison Symmes, stated on 12 March 1968 that, over the years, he was aware that it was impossible for the leader of a small Arab country, such as Lebanon or Jordan, to make separate peace with Israel, and that Jordan was the most moderate and rational, so we must talk to them to hold separate talks with it about peace with Israel as a desperate last resort. Symmes stated that he knew very well that King Hussein

13. Telegram From the Embassy in Jordan to the Department of State, Amman, 2 March 1968, 1725Z. 3672, Subject: Letter from King Hussein to President Johnson, Ref: State 113645 .

14. Doc. 128960, Telegram From the Department of State to the Embassy in Jordan, Washington, 12 March 1968, 0007Z. 
and many Jordanian leaders wanted a peaceful settlement with Israel but this desire for peace may not come to fruition due to the worsening situation in Jordan, especially as Israel continued to pursue policies that tended to consolidate its occupation of the West Bank. He added that the strategy of manipulation that Israel pursued by launching retaliatory raids against Jordan and the official and semi-official Israeli threats related to revenge against Jordan did not help in this. He further stated that the operations were bound to increase due to the policies pursued by Israel. According to Symmes, developments had shown that it would become more difficult for the Jordanian regime to suppress Palestinian organizations and these posed a major threat to the Jordanian regime itself. He added that if the stalemate in the peace efforts continues in the Gunnar Jarring Peace Mission ${ }^{15}$, then failure will occur not only in achieving multiple peaceful settlements but also in the chances of a successful move towards a peaceful settlement between Jordan and Israel, which will become very few, and the outlook for a stable and independent Jordan will become "darker". ${ }^{16}$

When Symmes met King Hussein on 14 March 1968, he expressed his concern about the return of hostilities to Palestinian organizations, as had happened in the few days before their meeting. Symmes confirmed that his information indicates that the Palestinian organizations are still working strongly in the Jordan River region against Israel and that, in view of the previous events, it was feared that Israel would retaliate, even though King Hussein has a policy against these organizations. In this meeting, King Hussein told Sims that he wanted the withdrawal of Iraqi forces from Jordan, and that, once the American weapons arrived, he would be in a strong position to remove the Iraqis. Symmes expressed his hope that the king would begin his efforts against the Palestine Battalion 421 backed by Iraq and present on Jordanian territory, and King Hussein responded that he was doing everything he could to limit the activity of these organizations. At that time, it seemed from Symmes' point of view that the Israelis were doing some things that did not undermine the operations, the most important of which were unilateral Israeli actions, especially its retaliatory actions against Jordan. These actions severely weakened Jordan's argument that it did not need Iraqi forces on its soil, especially since Iraqi Chief of Staff Ibrahim Faisal Al-Ansari (19671968) had announced he wanted to visit Jordan soon and that King Hussein would do everything in his power to get Iraqi forces out of his country. King

15. The Jarring Mission refers to efforts undertaken by Gunnar Jarring to achieve a peaceful settlement of the conflict between Israel and its Arab neighbors following the SixDay War in 1967. He was appointed on 23 November 1967 by UN Secretary-General, U Thant, as Special Envoy under the terms of UN Security Council Resolution 242 to negotiate the implementation of the resolution.

16. Doc. 3770. 1, Telegram From the Embassy in Jordan to the Department of State, Amman, 12 March 1968, 1615Z. 
Hussein expressed his hope that Israel would not make this matter impossible. King Hussein also agreed that the operations harmed the Arab cause more than it assisted them. ${ }^{17}$

In a telegram from the American embassy in Jordan to the US State Department on 19 March 1968, King Hussein revealed the decision taken by Iraqi Chief of Staff Ibrahim Al-Ansari to gradually withdraw Palestinian battalion 421 from Jordan to Iraq within just a week. ${ }^{18}$

It is possible to analyze King Hussein's position that he did feel that there was a real danger to him and his throne, as the presence of Palestinian armed organizations, some Iraqi forces, and many external circumstances imposed many challenges on him, so requesting weapons from the United States was part of his defense in case this evolved into an existential threat to him.

\section{The Bombing of the Israeli Bus and the Escalation of Tension}

During this American diplomatic move to at least reduce tension and achieve peace between Jordan and Israel, Israeli Defense Minister Moshe Dayan (5 June 1967 - 3 June 1974) on 17 March 1968, warned that Palestinian guerrillas were preparing for a new wave of resistance, which Israel would take as an excuse to do what King Hussein was unable to do, that is, eliminating the Palestinian organizations. Israeli Prime Minister Levi Eshkol (26 June 1963 - 26 February 1969) also warned of this issue in the Knesset. On the same day, Yosef Tekoah (1968-1975), the Israeli ambassador to the United Nations, filed a complaint with the United Nations against what he called "the Arabs repeated acts of aggression". ${ }^{19}$

The next day, 18 March 1968, an Israeli school bus was detonated by a landmine 13 miles north of Eilat, killing two people (a doctor and trainer) and wounding ten children ${ }^{20}$. This operation was the thirty-eighth of the Fatah movement within three months. That night, the Israeli cabinet approved the attack on the Al-Karameh, and Israel assumed that Jordanians would stand neutral and ignore the Israeli attack. ${ }^{21}$

17. Doc. 3793, Telegram From the Embassy in Jordan to the Department of State, Amman, 14 March 1968, 0820Z, Subject: Terrorism.

18. Doc. 3887, Telegram From the Embassy in Jordan to the Department of State, Amman, 19 March 1968, 1915Z, Subject: Terrorism.

19. "Foray into Jordan", Time, Friday, 29 March 1968. http://content.time.com/time/ magazine/0,9263,7601680329,00.html

20. Doc. 3887, Telegram From the Embassy in Jordan to the Department of State, Amman, 19 March 1968, 1915Z. Subject: Terrorism; Amir Oren, "Debacle in the Desert", Haaretz, 13 May 2011; https://www.haaretz.com/1.5011697; Morris. Righteous Victims, 368.

21. "1968: Karameh and the Palestinian revolt", Telegraph, 1 May 2002. 
Symmes mentioned that King Hussein decided to send Colonel Muhammed Daoud (Jordanian liaison with Israel) to meet his Israeli counterpart under the auspices of the United Nations in the next few days to contain the tension. The Israeli government made intensive efforts to arrest those responsible for the bus bombing and requested any information that might help her in the investigation. This request made King Hussein to speculate in some detail about Israeli intentions towards Jordan while he was reviewing Arab military capabilities with his advisers. He expressed his conviction of the complete inability of the Arabs to win a military solution in any military confrontation with Israel. Iraqi Chief of Staff Ibrahim Al-Ansari informed King Hussein that Iraq could no longer help Jordan militarily against Israel. In return, King Hussein expressed his doubts about the Israelis and their desire for peace. It was concluded that Israel wanted to retain the Arab land it occupied for religious and cultural reasons, that it needed to occupy certain additional areas to reinforce its position, and that Jordan was the target of Israeli occupation. $^{22}$

As for the Israeli bus bombing, King Hussein reminded Symmes that he had been "put into hell" and affirmed that if the perpetrators were arrested in Jordan, they would receive the same punishment as if they had caused this accident to the Jordanians. He added that he had sent senior investigators, including trackers, to the area of the accident near Aqaba and yet they did not discover any evidence that any person from Jordan's territory in that area had crossed into the border. King Hussein also mentioned that the Jordanian intelligence service, through breaches and investigations, was unable to discover any known Palestinian organization's involvement in this incident and that investigations were still ongoing under his personal supervision. The king indicated the possibility that there would be Egyptian foreign involvement in that incident ${ }^{23}$ and he said it would be desirable to inform the Israelis Update on the Israeli bus accident, the Palestinian battalion 241, and the dispatch of Colonel Muhammad Dawud. King Hussein warned that if the Israelis announced that the exit of the Palestinian battalion from Jordan resulted from Israeli pressure, he would not be able to allow her to leave later, and his efforts in this regard would be seriously compromised. ${ }^{24}$

The US State Department sent a telegram to the American Embassy in Israel on 20 March 1968, in which it stated that the Israeli ambassador to Washington, Yitzhak Rabin, had been called at 15:00 Washington time to clarify the following points.

22. Doc. 3887, Telegram From the Embassy in Jordan to the Department of State, Amman, 19 March 1968, 1915Z, Subject: Terrorism.

23. Ibid.

24. Ibid. 
a. The United States government is deeply concerned about reports from its embassy in Jordan and other indications that Israel is calling in reserve soldiers and taking measures that indicate its desire to carry out imminent military retaliation against Jordan.

b. The United States of America understands the feeling of anger in Israel after the attack on the Israeli school bus; however, the United States considers that the Israeli military reprisals are self-defeating and would seriously harm the hopes of a peaceful solution to the problems of the region.

c. More Israeli retaliatory actions against Jordan would be a major and perhaps fatal blow to the Jarring Peace Mission and to American interests in Jordan and would seriously undermine the ability of the United States to influence the Arab position to achieve constructive directions that are in Israel's best interest as much as it is in the interests of the United States.

d. Any Israeli military retaliation will be a regrettable measure at a time when it appears that Jordan will take steps to fight the resistance, which is what Israel has been seeking for a while. ${ }^{25}$

In a memorandum from Rostow, the Assistant to US President Johnson on 20 March 1968, Rostow confirmed that the Israelis were massing their forces on the border with Jordan, even though the American ambassador to Israel Walworth Barbour (11 May 1961 - 19 January 1973) confirmed that the Israeli decision of the final attack on Jordan had not yet been taken and that the rapid Israeli military move stemmed from the growing concern about the continuation of the Palestinian resistance. Barbour added that the Israelis did not believe that King Hussein made a real and sufficient effort to suppress Palestinian organizations and that after the bombing of the Israeli bus and similar incidents of sabotage, the pressure for revenge in Israel had become irresistible. So King Hussein asked the United States to help repel the Israelis because he feared that a major Israeli attack on his country would be the end, leading to the elimination of the Jarring Peace Mission. Rostow stressed that this would make the US position unhappy, especially if Israel decided to occupy additional lands of Jordan. ${ }^{26}$

Because of the escalating tension in the Middle East, and because of the Israeli build-up on the Jordan border, the US State Department sent a telegram from US President Johnson to the American embassy in Israel on 21 March 1968, and they were asked to deliver it urgently to Israeli Prime Minister Levi Eshkol as follows. Johnson Deplores what he called recent operations against

25. Doc. 133284. 1, Telegram From the Department of State to the Embassy in Israel, Washington, 20 March 1968, $1943 Z$.

26. Action Memorandum From the President's Special Assistant (Rostow) to President Johnson, Washington, 20 March 1968, 7:25 p.m. Subject: Urgent Message to Eshkol. 
Israeli lives and property. Nevertheless, he fully expressed his conviction that any military retaliation against Jordan would be a major error in appreciation and would have devastating consequences for hopes of peacemaking and the future of the region. He added that it was in the interest of the United States and Israel that no such action should be taken and he was making his effort for King Hussein to in return make every effort to stop the resistance. ${ }^{27}$

In a similar step, Johnson sent a telegram on the same day to teleport it quickly to King Hussein, expressing his appreciation for King Hussein's efforts to control Palestinian organizations and prevent incidents like the bus bombing on March 18, 1968, that could destroy hopes for peace in the Middle East. Johnson appealed to King Hussein to make every effort to put such incidents under strict control and that King Hussein must resolve to maintain an environment free from this kind of violence. He added that he appealed to Israeli Prime Minister Levy Eshkol in return for the exercise of restraint. ${ }^{28}$

Menachem Begin, the Israeli minister (without portfolio), stated that during the day before the Battle of Al-Karameh, Israel received five different messages from the United States of America, including one from President Johnson himself, asking her to refrain from a military operation. ${ }^{29}$

It was clear that the United States wanted to maintain stability in the constantly tense Middle East and did not want a new war by Israel against the Arabs, especially since Israel had just emerged victorious over them in the SixDay War. At the same time, the States have never wanted to lose its ally Jordan in a region teeming with countries hostile to it and its policy in the region.

\section{The Beginning of the Battle of Al-Karameh}

After Israel's shocking victory in the 1967 Six-Day War, the Israel Defense Forces (IDF) expected that any operation in the Jordanian town of Al-Karameh would be "a picnic" ${ }^{\prime 30}$. Since by 20 March 1968, Jordan was fully aware of the various Israeli military build-ups, the Jordanian army had taken positions near the bridges separating the two countries, and the artillery had been

27. Doc. 133886, Telegram From the Department of State to the Embassy in Israel, Washington, 21 March 1968, 0511 .

28. Doc. 133887, Telegram From the Department of State to the Embassy in Jordan, Washington, 21 March 1968, 0540Z.

29. Knesset Foreign Affairs and Defense Committee meetings, June 1967 - June 1968: the complete transcripts. Part 2, 22 March 1968: Transcript No. 111.

30. Michel Warschawski, "Karameh: The Palestinian Resistance's 1968 Baptism of Fire", Verso, 13 May 2018. https://www.versobooks.com/blogs/3800-karameh-the-palestini an-resistance-s-1968-baptism-of-fire. 
deployed to the upper Jordan Valley highlands overlooking the town of AlKarameh to obtain a strategic advantage. ${ }^{31}$

Prior to the Israeli attack on Al-Karameh, the IDF Chief of Staff, Haim Bar-Lev (1968-1971), stated that the Israeli Air Force (IAF) threw leaflets informing the Jordanian army that Israel had no intention of harming them and that they should not interfere in any upcoming battle. The leaflets did not receive any attention but rather led to Palestinian fighters heading in large numbers to confront Israeli forces in the town of Al-Karameh. ${ }^{32}$

At 5:30 am on 21 March 1968, the Israeli forces attacked at the same time the Jordan River through the bridges that separated them from Jordan ${ }^{33}$, where soldiers and paratroopers crossed, alongside tanks, armored vehicles and other vehicles, Allenby Bridge south of Al-Karameh and Damiya Bridge north of it in a movement of pincers to attack Palestinian militants in two directions. Israeli forces also moved south of the Dead Sea near the town of Ghor Al-Safi, and paratroopers were dispatched east of Al-Karameh to cut off the road to any withdrawal of Palestinian fighters ${ }^{34}$. When the Israeli forces began their incursion into Al-Karameh, they met stiff resistance by Fatah movement fighters and other Palestinian organizations backed by artillery and Jordanian forces. ${ }^{35}$

The Israeli forces in charge of the attack penetrated the town of AlKarameh at 7:00 $\mathrm{am}^{36}$, and by 8:00 am, they took control of the town. These forces discovered that Al-Karameh was the largest base of the Palestine Liberation Organization (PLO) previously perceived. ${ }^{37}$

Despite the partial success achieved by the Israeli forces in Al-Karameh, these forces were frustrated by their inability to surround the entire forces of the PLO factions, especially Fatah movement, and were surprised by the violent resistance of these factions and the standing of the Jordanian army on their side. Their frustration was further aggravated by their inability to achieve rapid victory as they had hoped and as was the case in all their

31. Kenneth M Pollack, Arabs at War: Military Effectiveness, 1948-1991 (Lincoln: University of Nebraska Press, 2002), 331-332.

32. Knesset Foreign Affairs and Defense Committee meetings, June 1967 - June 1968: the complete transcripts. Part 2, 26 March 1968: Transcripts Nos. 113-114.

33. Doc. 133886, Telegram From the Department of State to the Embassy in Israel, Washington, 21 March 1968, 0511Z (Note: 3); Pollack, Arabs at War, 332-333.

34. "Battle of Al-Karama, A Triggering Moment for the Palestinian Resistance", Palestinian journeys.

35. Pollack, Arabs at War, 332-333.

36. Morris, Righteous Victims, 369.

37. Chaim Herzog and Shlomo Gazit, The Arab-Israeli Wars: War and Peace in the Middle East from the War of Independence through Lebanon (New York: Vintage Booke, 1982), 205. 
previous wars. So the IDF leadership decided to withdraw but later had to fight again to withdraw from Jordan. ${ }^{38}$

\section{The End of the Battle of Al-Karameh}

The IDF began withdrawing on the same evening, during which 156 fighters of the PLO factions were killed, about 100 others were wounded, and 141 others were captured ${ }^{39}$. The Jordanian forces lost between 40-86 soldiers, with 108-250 soldiers were wounded ${ }^{40}$. As for Israel, it lost 28-33 soldiers, with 69-161 were wounded; 27 tanks were destroyed, and 4 other tanks were left behind. ${ }^{41}$

The relatively high Israeli losses were big and surprising for the Israelis ${ }^{42}$, and this was why the battle of Al-Karameh provided a huge boost and a great propaganda service for the PLO and Fatah factions ${ }^{43}$. This battle immediately became a synonym for Palestinian courage and valor, less than one year before Israel defeated the Arab armies in the Six-Day War. The battle of AlKarameh was not merely a victory in a battle but a history that brought the Palestinian issue and the Palestinians back to the political map. ${ }^{44}$

The chief of bureau of the then Israeli Foreign Ministry, Gideon Rafael (1968-1972), admitted when he said: "The operation gave an enormous lift to Yasser Arafat's Fatah movement and irrevocably implanted the Palestinian problem onto the international agenda, no longer as a humanitarian issue of homeless refugees but as a claim to Palestinian Statehood."45

The battle of Al-Karameh also made Arabs and Palestinians realize that Israel could be defeated and forced to recalculate its potential ${ }^{46}$, and they

38."Foray into Jordan", Time, 29 March 1968.

39. Morris, Righteous Victims, 369.

40. Zeev Maoz, Defending the Holy Land, A Critical Analysis of Israel's Security and Foreign Policy (Michigan: University of Michigan Press, 2009), 244-246; Steve Posner, Israel Undercover Secret: Warfare and Hidden Diplomacy in the Middle East (New York: Syracuse University Press, 1984), 181; Suzanna Goussous, "UJ celebrates 47th anniversary of Karameh Battle", The Jordan Times, 26 March 2015. http://www.jordantimes.com/news/lo cal/uj-celebrates-47th-anniversary-karameh-battle.

41. Herzog and Gazit, The Arab-Israeli, 205; Morris, Righteous Victims, 369.

42. Tucker and Roberts. Encyclopedia of the Arab-Israeli Conflict, I, 569-573.

43. Jewdayo Grid, "March 21: Battle of Karameh", Jewish Current, 20 March 2011. https://jewishcurrents.org/march-21-battle-of-karameh/.

44. "1968: Karameh and the Palestinian revolt", Telegraph, 1 May 2002.

45. Grid, "March 21: Battle of Karameh"; Warschawski, "Karameh: The Palestinian Resistance's 1968 Baptism of Fire".

46. Jawad Anani, "The Karameh Battle", The Jordan Times, 19 March 2018. https:// www.jordantimes.com/opinion/jawad-anani/karameh-battle 
considered it a psychological victory over the IDF, which was seen as invincible after its victory in three battles against Arabs. ${ }^{47}$

\section{The American Reaction to the Battle}

Harold H. Saunders of the National Security Council sent a memo to President Johnson on 21 March 1968, informing him that Israel had begun a major attack on the bases of Palestinian organizations on the eastern bank of the Jordan River. Saunders confirmed that Johnson's message to Eshkol arrived after the attack (8:45 pm EST), that Eshkol told him that this raid would be "limited", and that the Israeli forces would withdraw as soon as they finished their mission to prevent and disarm the activities of Palestinian organizations. ${ }^{48}$

Saunders emphasized in this memo that the United States faced three issues.

1. The United States would likely delay the signing of the US Aid Agreement to Israel, known as PL480, which was to be signed at 10:30 am on 21 March 1968 US time, and Saunders confirmed that he did not see an opportunity to sign this new agreement on the same day and that it was necessary for the United States to say that everyone would be "very busy" that day, avoiding any indication that this delay was punishment for anyone.

2. The United States was considering issuing an early statement based on the idea that more violence cannot bring peace to the Middle East and that "our concern and dismay" be expressed about Israeli military action against Jordan, and that it could hardly be silent about that, with the need to be as cautious as possible towards local Jewish opinion in the United States.

3. Saunders confirmed that he had no indication until that time that there would be a meeting of the United Nations Security Council, but the possibility of this happening was clear. ${ }^{49}$

After the battle for Al-Karameh began, King Hussein sent President Johnson on 21 March 1968, a message saying: "We are now fighting once again, defending ourselves in the face of blatant and deliberate Israeli aggression". King

47. A.I. Dawisha, Arab Nationalism in the Twentieth Century: From Triumph to Despair (Princeton: Princeton University Press, 2003), 258.

48. Information Memorandum From Harold H. Saunders of the National Security Council Staff to President Johnson, Washington, 21 March 1968, 7:45 a.m.

49. Ibid. 
Hussein affirmed that he was defending his country in this war with the remaining weapons in their hands since the June 1967 war in light of the lack of a final agreement with the "friendly" United States to re-supply Jordan with defense equipment. He added that it was because of Israeli aggression that Jordan, its Head of State, leaders, armed forces, and people have all become "victims" of American weapons, and that his faith and belief in the friendship between Jordan and the United States and its president made Jordan to reject any other choice from any country to strengthen his defensive weapons in the face of the history of the continuing aggression of Israel. King Hussein affirmed that neither he, his government, nor his armed forces would bear and would not be responsible for the safety and security of the Israeli occupation forces in the West Bank and the rest of the occupied Arab territories and that he was not expected to be responsible for this matter. ${ }^{50}$

King Hussein also affirmed once again that after a thorough investigation into the incident of the Israeli bus bombing, no conclusion had been reached regarding the perpetrators in Jordan. He added that he was doing his best honestly and sincerely to lay the foundation for a just and lasting peace in the region, and that if there was blame because of the failure, it must fall directly on the Israeli side and on those who encouraged Israel knowingly or unknowingly in its plan to destroy the first and last opportunity to achieve peace. ${ }^{51}$

The US Ambassador in Amman Symmes mentioned that the message of the American President to King Hussein on 21 March 1968, had reached him three hours after the Israeli attack on the town of Al-Karameh began within the Jordanian border, and that this message had sparked a very negative reaction from King Hussein. He added that it appeared that the king was particularly upset by what he considered a hint that the United States of America held Jordan responsible for the Israeli bus bombing and that he was not sincere in efforts to control Palestinian organizations. ${ }^{52}$

King Hussein's position was apparently sincere if we knew that after decades, no one could prove that the Palestinian organizations were the ones that blew up the Israeli bus and none of them had claimed responsibility for this incident, which really raises many questions about who carried it out.

50. Doc. 3928, Telegram From the Embassy in Jordan to the Department of State, Amman, 21 March 1968, 1030Z.

51. Ibid.

52. Ibid. 


\section{Security Council Resolution 248 and its implications}

After the battle of Al-Karameh ended, the UN Security Council adopted Resolution 248 on 24 March 1968, unanimously (15 countries, including the United States of America), and the resolution states as follows.

1. Regret over the loss of life and serious damage to property.

2. Condemn the military action launched by Israel in flagrant violation of the United Nations Charter and ceasefire resolutions.

3. Denounce all violent incidents that violate the ceasefire, and declare that military reprisals and other grave ceasefire violations cannot be tolerated.

4. Call on Israel to desist from actions or activities contrary to Resolution 237 (of 1967). ${ }^{53}$

\section{The American Position after the Battle Was over}

The American ambassador to the United Nations Arthur Goldberg (28 July 1965 - 24 June 1968) said: "We believe that the military counteractions, such as those that have just taken place, on a scale out of proportion to the acts of violence that preceded it, are greatly to be deplored." ${ }^{54}$

Israeli Foreign Minister Abba Eban (13 January 1966 - 2 June 1974) also spoke about the harsh reactions to the Al-Karameh battle around the world, stressing that the American position was particularly troublesome, given that the United States considered the operation a disproportionate and unnecessary attack. The matter ultimately led to an increase in Fatah movement's power. ${ }^{55}$

In a media note from Rostow to President Johnson on 22 March 1968, Israeli Prime Minister Levi Eshkol, who mentioned the Israeli justifications for their recent attack on Jordan, replied that the Israelis had gathered much evidence that Palestinian organizations were planning a coordinated attack in the spring and summer of 1968 within Israeli territories. Eshkol claimed that the Israelis seized Soviet documents and weapons to prove this. While Eshkol was working to achieve better control of the borders with Jordan, Symmes was assuring him of the United States' determination to return attention and focus to the Jarring Peace Mission. He added that the debate on this mission and the possibility of its success was still continuing and that a future mission

53. United Nation, Security Council, S/RES/248 (1968, Resolution 248, 24 March 1968.

54. Grid, "March 21: Battle of Karameh".

55. Knesset Foreign Affairs and Defense Committee meetings, June 1967 - June 1968: the complete transcripts, Part 2, 9 April 1968: Transcript No. 115. 
would also depend on the results of the Arab Summit that King Hussein requested to convene after the Israeli attack on the town of Al-Karameh. ${ }^{56}$

As for the Israeli Prime Minister, he said on 22 March 1968, that Israel received a clear message from the American administration that the largescale military operation contradicts American interests in the region. Eshkol explained to the American administration that Israel would proceed in diplomatic talks with Jarring as scheduled ${ }^{57}$. On the day, the US State Department sent a telegram to the American Embassy in Israel on 23 March 1968, reporting that Eshkol reviewed the Palestinian military operations, the most recent of which was the "Gruesome attack" on the Israeli bus carrying Israeli children on 18 March 1968, confirming that Fatah movement had decided to develop its operations against Israel by undertaking open, frank, organized, and legitimate operations in the eyes of King Hussein, instead of carrying out secret operations only. This would be done during the spring and summer of 1968. The Jordanian leaders tolerated and sometimes encouraged violations against the security of the State of Israel and did not contribute to a ceasefire or the implementation of international obligations, which threatened Jordan's independence and pushed Jordan and Israel towards conflict again. The telegram added that the attack by Israel on the town of Al-Karameh against Fatah movement should not cause any remorse for Israel, the Israeli government, or the United States, that it would be "destructive" for the United Nations to avoid its duty by harshly criticizing Fatah operations from Jordan against Israel. It further stated that orders had been issued to the IDF not to harm civilians in the battle of Al-Karameh, that this cost Israel a heavy price, and that King Hussein must understand that the Jordanian army was not a target of the Israel Defense Forces, although the Jordanian army sometimes succumbed to pressure from Fatah movement. ${ }^{58}$

The US State Department also stated that King Hussein was then better able to promote a ceasefire and move toward peace through negotiations and that Israeli Foreign Minister Aba Eban told Jarring that the Israeli government was still accepting his proposal to hold a peace conference with Arab countries in Nicosia. He added that it would work with him patiently despite Jamal Abdel Nasser's irresponsible rejection of this proposal ${ }^{59}$. Aba Eban once again considered that the Jordanians were still showing their readiness for peace with Israel. He spoke with the American administration, which asked

56. Information Memorandum From the President's Special Assistant (Rostow) to President Johnson, Washington, 22 March 1968, 7:35 p.m. Subject: Reply from Eshkol.

57. Knesset Foreign Affairs and Defense Committee meetings, June 1967 - June 1968: the complete transcripts. Part 2, 22 March 1968: Transcript No. 112.

58. Doc. 135561. 1, Telegram From the Department of State to the Embassy in Israel, Washington, 23 March 1968, 2001Z.

59. Ibid. 
Israel to reduce its actions in East Jerusalem and make some gestures towards Palestinian refugees to persuade Jordan to move towards peace. ${ }^{60}$

In a memo to President Johnson on 26 March 1968, Rostow said that after weeks of negotiation, the arms deal for Jordan was ready to be signed and that the plan was to sign the deal without announcing it after negotiations that lasted a few weeks. That time may not have been the best time to announce the deal in light of the ongoing Palestinian attacks against Israel and the Israeli attack on Al-Karameh within the Jordanian borders. However, there may not be any good time to announce the deal, and the main purpose of this matter was to strengthen the authority of King Hussein, although the weapons in this deal would not reach Jordan at the same time. ${ }^{61}$

It seems that the United States wanted this deal to balance its relationship with Jordan on the one hand and with Israel on the other, and that the approval of this deal was a kind of compensation for the Israeli attack on Jordan. It may also have been an attempt to encourage Jordan to continue peace efforts and to fight the operations carried out by Palestinian organizations against Israel.

Therefore, Rusk gave a fresh indication that the United States would make efforts again to prevent further Israeli attacks on Jordan, that the United States' opposition to Israel's retaliatory raids on Jordan came as it does towards opposing operations against Israel. He added that the United States appreciated that the problem of King Hussein lay in controlling Palestinian operations in light of the lack of progress towards a peaceful settlement. He further stated that no Israeli government could resist the pressure of the internal policy that drove them to take another military action if operations continued in Israeli territory, and as regards the increasing intensity of these operations, security considerations had always prevailed over the Israeli government. $^{62}$

Rusk stressed that it was clear that achieving a just and acceptable peace on both sides was the only true solution to the problem of Palestinian operations and that the ways in which the United States can assist Jarring's efforts to achieve a peaceful settlement should be actively examined. However, if the cycle of Palestinian operations and Israeli reprisal raids continues, the situation will rapidly deteriorate to the point of no return. Rusk stated that work should continue for more flexibility in the Israeli position, but at the same time, it was necessary for Jordanians to show a great deal of control over

60. Knesset Foreign Affairs and Defense Committee meetings, June 1967 - June 1968: the complete transcripts. Part 2, 19 March 1968: Transcript No. 110.

61. Action Memorandum From the President's Special Assistant (Rostow) to President Johnson, Washington, 26 March 1968, 8:10 p.m. Subject: Signing Jordan Arms Package.

62. Doc. 137662, Telegram From the Department of State to the Embassy in Jordan, Washington, 28 March 1968, 0138Z. 
the activities of Palestinian organizations. Unfortunately, the United States had no plan to present to the Jordanians to control the organizations. Rusk stressed that the US government was not absent from the Jordanian government's efforts or the moderate and constructive course that it followed and that they were concerned about the situation that appeared to be going in dangerous directions away from peace. ${ }^{63}$

The US administration emphasized once again that the operations carried out by Palestinian organizations pose a threat, and Israel must do what is necessary towards it, and that Israel's efforts to end these operations through military counterattacks will not succeed. It added that if they continued on that path, everyone would see an endless spiral of attacks and counterattacks and all the Arabs at the Arab Summit would continue to reject a political solution and declare their commitment to the guerrilla war carried out by the Palestinian organizations against Israel and that the Israelis are beginning to understand this thing, even though they feel that they had to respond to these operations in one way or another. ${ }^{64}$

The US administration also confirmed that the only party that could stop operations from Jordanian territory was the Jordanian government. Consequently, the problem was to persuade King Hussein to stop these actions or work to create conditions that would enhance his standing enough to suppress them, with an agreement that Israeli military attacks do not enhance his standing. It added that it may not be too late for King Hussein to neutralize Palestinian organizations or stop them by force, and that the alternative to violence lay from the point of view of the US government in putting the Jarring peace talks on the road, and that the alternative to peace was to allow the force to play its role. ${ }^{65}$

The administration also stressed that the problem was that only the Israelis decide to shoot when the pressure of Palestinian operations against them escalates, leaving the United States in a worse position every time Israel responds, in light of the real risk that the Security Council will vote the United Nations to impose sanctions against Israel, and most importantly, that Israel was also in a worse situation if it does not stop the spiral of guerrilla war. ${ }^{66}$

In a conversation, Harold Sand Rice and Ephraim Evron, the Israeli Minister at the Israeli Embassy in Washington, spoke basically about the Israeli attack on Al-Karameh town and what the Israelis see at the end of their course of escalating operations and counter-retaliatory attacks, although the results of the military review of the attack on the town of Al-Karameh were

63. Ibid.

64. Memorandum From Harold H. Saunders of the National Security Council Staff to the President's Special Assistant (Rostow), Washington, 29 March 1968, Subject: Next Step with Israel-Jordan.

65. Ibid.

66. Ibid. 
not yet over. Evron noted in this meeting that the Israelis were not necessarily satisfied with this type of attack as the best way to combat organizations and that they would test other methods like building a fence extending from the Dead Sea to the Sea of Galilee (Tiberias). He added that this was why Israel ordered so many anti-personnel mines as quickly as possible from the United States. Evron also stressed that he was fully prepared to recognize that Israeli counterattacks would not stop operations. ${ }^{67}$

When Sanders asked about his opinion of how the Israelis could expect to stop activities on grounds that Israelis did not control, Evron responded that the main problem was convincing King Hussein of the need to carry out the task of controlling his lands and preventing operations. Then Sanders told him that he did not believe that the Israeli counterattacks would do that either. Evron did not agree with him, but he did not argue with the same strength that he did before. Evron emphasized in this meeting that King "Hussein is so weak that perhaps only the Palestinians can take the led"68. However, the facts of the matters proved that Evron's words were false, as King Hussein was able, within only two years, to impose his authority and sovereignty on the ground and to permanently liquidate the Palestinian resistance and remove it from Jordan.

\section{The Balance Policy after the Battle of Al-Karameh}

American diplomacy did not stop after the battle of Al-Karameh, so Harold Sanders sent to Rostow on 1 April 1968, another memorandum stressing the need for US President Johnson to put pressure on Israel and begin to rebalance the position of the United States of America toward the Arabs. Sanders added that the best bet for the United States was to focus on changing Israel's position by persuasion - rather than pressure - to give the Jarring Pease Mission a real opportunity to achieve peace. He further stated that it must be ensured that doing something close to this was better than letting the forces in the Middle East play their role, given the possibility that the next Arab summit would commit to guerrilla war against Israel instead of a political solution. He added that called upon Israel to clearly signal that she did not want to put obstacles in the way of the Jarring Pease Mission, which was difficult in light of the

67. Memorandum for the Record, Washington, 29 March 1968, Subject: Conversation with Israeli Minister Evron.

68. Ibid. 
crisis of the Israeli cabinet and Eshkol's desire to preserve the coalition that made up his government. ${ }^{69}$

On 4 April 1968, US Undersecretary of State Nicholas Katzenbach sent a note to President Johnson expressing deep concern about the recent developments in the Middle East, which gave the Soviet Union the opportunity to exploit provocative operations and Israeli military retaliation against them. He added that it was clear that Palestinian guerrillas had strengthened their gains due to King Hussein's inability to deal with the matter due to his regime's apparent weakness, along with reduced sympathy for Israel and increased doubts about its peaceful intentions. Therefore, Jarring must try to secure some gestures on the part of the Israelis, and the Arabs should obtain some conviction regarding continued Israeli interest in reaching a political settlement, which would strengthen King Hussein's position. ${ }^{70}$

Nevertheless, on 5 April 1968, Rostow affirmed that Eshkol's approach to Jarring's Pease Mission was very general, while King Hussein expressed his willingness to accept this plan. Rostow added that there was an express judgment that if the United States failed on this tour, they would face a very grim possibility ${ }^{71}$, and this track confirmed Israel's demand for large quantities of antipersonnel mines $(400,000)$ from the United States. Evron said that the urgently needed mines coincided with the creation of a security belt to prevent the infiltration of Palestinian fighters along sensitive areas of the ceasefire line. The Deputy Assistant Secretary of State for Near East and South Asian Affairs, Rodger P. Davies (1965-1970), gave a personal response to Evron's request that since the United States government took a strong public stance criticizing Israeli's policy of military retaliation, it was preferable to cooperate in taking measures to provide alternatives to that policy. Rodger added that it would be embarrassing to use US-manufactured mines in military countermeasures to Jordan, so Evron quickly replied that he was authorized to announce to him that the mines would only be used in a project to close and guarantee the Israeli border at night only. ${ }^{72}$

Whatever the case, President Johnson expressed to Levi Eshkol his deep sympathy for the serious problems posed by the ongoing operations against Israel, as well as his deep concern about the prospects of not achieving peace in the Middle East. Yet Johnson expressed his belief that military action that crossed the ceasefire did not deter the kind of operations that Israel was facing but led to

69. Memorandum From Harold H. Saunders of the National Security Council Staff to the President's Special Assistant (Rostow), Washington, 1 April 1968, Subject: The President's Decision and the Near East.

70. Memorandum From Acting Secretary of State Katzenbach to President Johnson, Washington, 4 April 1968, Subject: Middle East Problem.

71. Action Memorandum From the President's Special Assistant (Rostow) to President Johnson, Washington, 5 April 1968, 9:20 p.m.

72. Doc. 142978. 1, Telegram From the Department of State to the Embassy in Israel, Washington, 6 April 1968, 0229Z. 
more insecurity. The president added that Israel's true security lay only in achieving peace, that everyone was at a crossroads in this regard in the Near East, and that the only peacemaking process available at that time was the Jarring Pease Mission. Johnson expressed his deep concern regarding the lack of tangible results for this mission and the accumulated deterioration of the situation resulting from the increase in military operations and countermeasures carried out by Israel, which seriously affected life in Jordan. He confirmed that there was very little time. However, there was still an opportunity for an active peace strategy, and this may be the last chance for the success of the Jarring Peace Mission. $^{73}$

The Battle of Al-Karameh ended, but the Jarring Peace Mission continued afterward. It could not achieve peace between Israel and the Arabs, nor bilaterally, between Israel and Jordan. As for the Palestinian organizations in Jordan, they were on a date with clashes between them and the Jordanian army, in what was known as the "Black September" events, which began in September 1970 and ended in July 1971 with the elimination of the presence of these organizations on Jordanian lands and their transfer to Lebanon, which became a starting point for Palestinian military action again against Israel.

\section{Conclusion}

The study concluded that the position of the United States of America was supportive of the right of Israel to defend itself against Palestinian military actions launched from Jordan. At the same time, the United States affirmed its position in favor of the sovereignty, independence, and territorial integrity of Jordan as its ally state. Therefore, it rejected the Israeli military countermeasures against Jordan before and during the Battle of Al-Karameh, considering that these measures were inconsistent with American interests in the region and would not stop these operations against Israel or give it the security it sought. The United States maintained that security could only be guaranteed by achieving peace. It also put pressure on the Jordanian King Hussein, incited him to act against the armed Palestinian organizations, and repeatedly demanded that he does his duty to stop Palestinian hostilities against Israel. Therefore, the United States' agreement to supply Jordan with defensive weapons -which did not disrupt the military balance with Israel may have come within the framework of that order, and this was confirmed in the next few years when Jordan, through the use of military force, permanently liquidated the presence of Palestinian organizations on its territory in 1970-1971.

73. Doc. 142988. 1, Telegram From the Department of State to the Embassy in Israel, Washington, 6 April 1968, 0516Z. 


\section{Bibliography}

Anani, Jawad. "The Karameh Battle", The Jordan Times, 19 March 2018. https://www.jorda ntimes.com/opinion/jawad-anani/karameh-battle

"Battle of Al-Karama, A Triggering Moment for the Palestinian Resistance", Palestinian journeys. https://www.paljourneys.org/en/timeline/highlight/165/battle-al-karama

Ciment, James World. Terrorism: An Encyclopedia of Political Violence from Ancient Times to the Post-9/11 Era, London: Routledge, 2011.

Dawisha, A.I. Arab Nationalism in the Twentieth Century: From Triumph to Despair, Princeton: Princeton University Press, 2003.

"Foray into Jordan", Time, Friday, 29 March 1968. http://content.time.com/time/magazine/ $0,9263,7601680329,00 \cdot \mathrm{html}$

Foreign Relations of the United States (FRUS), 1964-1968, Volume XX, Arab-Israeli Dispute, 1967-1968.

Gat, Moshe. Britain and the Conflict in the Middle East, 1964-1967: The Coming of the Six-Day War. Westport: Praeger, 2003.

Goussous, Suzanna. "UJ celebrates 47th anniversary of Karameh Battle", The Jordan Times, 26 March 2015. http://www.jordantimes.com/news/local/uj-celebrates-47th-anniver sary-karameh-battle

Grid, Jewdayo. "March 21: Battle of Karameh", Jewish Current, 20 March 2011. https:// jewishcurrents.org/march-21-battle-of-karameh/

Hanel, Rachael. Days of Change: The Israeli-Palestinian Conflict, Minnesota: The Creative CEducation, 2007.

Herzog, Chaim and Gazit, Shlomo. The Arab-Israeli Wars: War and Peace in the Middle East from the War of Independence through Lebanon, New York: Vintage Booke, 1982.

Knesset Foreign Affairs and Defense Committee meetings, June 1967 - June 1968: the complete transcripts. Part 2, February- April 1968.

Maoz, Zeev. Defending the Holy Land, A Critical Analysis of Israel's Security and Foreign Policy, Michigan: University of Michigan Press, 2009.

Morris, Benny. Righteous Victims: A History of the Zionist-Arab Conflict, 1881-1999, New York: Vintage Books, 2001.

Oren, Amir. "Debacle in the Desert", Haaretz, 13 May 2011. https://www.haaretz.com/ 1.5011697

Pollack, Kenneth M. Arabs at War: Military Effectiveness, 1948-1991, Lincoln: University of Nebraska Press, 2002.

Posner, Steve. Israel Undercover Secret: Warfare and Hidden Diplomacy in the Middle East, New York: Syracuse University Press, 1984.

Tucker, Spencer C. and Roberts, Priscilla. Encyclopedia of the Arab-Israeli Conflict, The: A Political, Social, and Military History, Vol. 1, Santa Barbara: ABC-CLIO, 2008.

United Nation, Security Council, S/RES/248 (1968), Resolution 248, 24 March 1968.

Warschawski, Michel. "Karameh: The Palestinian Resistance's 1968 Baptism of Fire", Verso, May 13, 2018. https://www.versobooks.com/blogs/3800-karameh-the-palestinian-re sistance-s-1968-baptism-of-fire

Zanotti, Jim. "Palestinians: Background and U. S. Relations", Congressional research service, 8 January 2010.

"1968: Karameh and the Palestinian revolt", Telegraph, 1 May 2002. https://www.telegra ph.co.uk/news/1400177/1968-Karameh-and-the-Palestinian-revolt.html 
